\title{
Residents' Opinions about the Sustainability of Tourism: Selimiye Village-Turkey
}

\author{
Dr. Funda Varnaci Uzun ${ }^{1}$
}

\begin{abstract}
Given the importance of resident in ensuring sustainability in tourism destinations, the purpose of the current study is to evaluate the residents' opinions about the sustainability of tourism in Selimiye Village, where there are intense tourism activities. To this end, the answers to the questions "What are the residents' opinions about the sustainability of tourism activities in Selimiye Village?" and "Do the residents think that tourism activities in Selimiye Village are sustainable?" were sought in the current study.

Located within the borders of Datça-Bozburun Special Protection Area, Selimiye Village is a coastal village in southwest Anatolia. As a result of the developing access to the village on land, the village has experienced a fast growth in the last two decades.

In the current study, data were collected through the face-to-face in-depth interview technique using a semi-structured interview form. As a result of the descriptive analysis of the residents' opinions, it was concluded that unless the necessary precautions are taken, the tourism in Seimiye Village cannot go on in a sustainable manner.
\end{abstract}

Keywords: Sustainable Tourism, Residents, Local People, Selimiye Village, Marmaris, Turkey

\section{Introduction}

Tourism is one of the most important sectors of the world, which has sociocultural benefits for both tourists and residents, also directly and indirectly contributing to local economies (Lozano-Oyolaa, Blancas, González, \& Caballero, 2012). Tourism is becoming an important component of economic development programs around the world. At the same time, residents in many areas are encountering tourism's impacts and benefits for the first time (Harrill, 2004). A host community of tourism destinations experience diverse consequences of tourism development. Typically these tourism consequences have been articulated in the categories of economic, socio-cultural, and environmental effects, which generally either positively or negatively impact a local community ( $\mathrm{Yu}, 2011)$. The positive contributions of the development of tourism to the local community include the economic development of the people, increase in employment opportunities and increase in the quality of life while some problems can also be caused by this development such as the infrastructure problems during the tourism season, traffic and parking problems, environmental destruction, wastes and pollution, leading to deterioration in the life quality of residents (Almeida-García, PelaezFernandez, Balbuena-Vazquez, \& Cortes-Macias, 2016). Although tourism is seen as a sector that increases the economic gain of the residents, improves their welfare and reduces the need for other economic activities in many countries, its adverse effects such as changing land use and destruction of local cultures have been overlooked to a great 
extent (Akis, Peristianis, \& Warner, 1996). According to Butler (1980), at the start of the tourism activities in a destination, residents are pleased with tourists coming (Butler, 1980). Residents can benefit from tourism's economic impacts when tourists spend money in the local economy or their spending indirectly creates employment opportunities for residents. Tourism also requires the development and maintenance of infrastructure and facilities that residents enjoy (Lottig, 2007). However, due to the rapid development of tourism and its environmental negative effects and emerging excessive overload on the capacity of destinations in recent years, sustainability in tourism has started to gain greater importance (Lozano-Oyolaa, Blancas, González, \& Caballero, 2012).

Sustainable development has become an important and popular conceptual framework in the world with the Bruntland Report issued by the World Commission on Environment and Development (WCED) in 1987 (Lew, Ng, Ni, \& Wu, 2016). When the concept of sustainable tourism, which is developed under the theme of sustainability, is viewed as the adaptation of the Brundtland Report to tourism - it can be defined as "the type of tourism that meets the needs of tourists and residents without preventing future generations from meeting their needs". (Swarbrooke, 1999). Sustainable tourism is rooted in sustainable development in the sense that if tourism is to contribute to sustainable development, it must be economically viable, environmentally sensitive and socio-culturally appropriate (Kitnuntaviwat \& Tang, 2008). Economic sustainability ensures that development is economically efficient and that resources are managed in such a way that they can support future generations. Ecological sustainability is concerned with ensuring development that is compatible with the maintenance of essential ecological processes, biological diversity and biological resources. Social and cultural sustainability ensures that development increases people's control over their lives, is compatible with the culture and values of people affected by it, and maintains and strengthens community identity (Timur \& Getz, 2009). The development of sustainable tourisms depends on the attitudes of residents because residents play a critical role in decisions to be made and the provision of the labor force in the destination. In general residents' attitudes towards the development of tourism are positive as far as its economic benefits are concerned and are negative as far as it negative social and environmental impacts are concerned (Hsieh, Park, \& Huh, 2016). Tourism should develop in such a way as to strengthen the local economy, to provide job opportunities for residents, to ensure the sustainability of local products, to support local agriculture and to contribute to the protection and maintenance of local traditions (Cottrell, Vaske, \& Roemer, 2013).

In ensuring sustainable tourism, planning is one of the most critical issues. The environmental pollution and related problems caused by unplanned tourism movements results in the destruction of natural-cultural assets and the deterioration of activities related to agriculture-forest-fishing-apiculture-sponge fishing and losses of values that cannot be measured with money, and the collapse of tourism in the long run (Emekli, 2004). In cases where there is no understanding of planning and management in tourism, adverse effects such as loss of biodiversity, increasing pressure on natural resources, pollution of water, air and soil, destruction of natural and cultural resources, visual pollution and deterioration in the socio-cultural structure of residents are encountered. 
(Cengiz, 2012). If tourism is not carried out with good planning, it leads to the destruction of local cultures and identities (Andereck, Valentine, Knopf, \& Vogt, 2005). Lack of tourism planning can also limit the amount of tourist spending that directly benefits residents. For instance, large tourism suppliers based in other countries, though they do pay wages to local workers, also export a large share of the revenues to their corporate headquarters creating economic leakage from the destination. Additionally, the jobs created by the tourism industry may be low-skill, low-status work with low pay (Lottig, 2007).

Residents who are directly affected by the development of tourism and its positive and negative effects should be the main element to be focused on in tourism planning and in ensuring sustainability in tourism (Choi \& Sirakaya-Turk, 2005). With the recognition that the effects of tourism mostly occur on local communities, residents' opinions about the sustainable development of tourism have also started to gain greater importance (Almeida-García, Pelaez-Fernandez, Balbuena-Vazquez, \& Cortes-Macias, 2016). The sustainability and development of tourism in a destination depend on residents' perception of the development and effects of tourism (Rasoolimanesh \& Jaafar, 2017). Tourism's positive and negative impacts also play a significant role in shaping resident attitudes toward tourism (Boley, 2013). With residents' improving positive perception of tourism, their satisfaction with and appreciation of tourism also increases. This is of vital importance for long-term sustainability of tourism (Kim, Uysal, \& Sir, 2013). If tourism is developed to be a main source of economic development in a destination, a positive interaction between tourists and residents is necessary to maintain the success of tourism. To facilitate this positive interaction it is critical that their attitudes, perceptions and levels of satisfaction are understood. Understanding that residents must contend with the impacts of tourism year-round is especially important for planners and developers to understand (Knollenberg, 2011).

In developing countries, local community involvement in decision-making in tourism planning is often ignored. Participation of society in decision-making processes, which is an integral part of sustainable tourism, is the basis of planning and management in tourism (Eshliki \& Kaboudi, 2012). Community involvement is considered to be the cornerstone of sustainable tourism development, as this concept has received resounding endorsement as a fundamental principle of sustainability (Nicholas, Thapa, \& Ko, 2009). For sustainability, it is important to understand and evaluate residents' perceptions of and attitudes towards tourism development (Choi \& Murray, 2010). Residents' expectations of tourism, perspectives on tourism and perceptions of the natural and cultural values play an important role in the development of sustainable tourism planning and management strategies (Cengiz, 2012). To gain support for tourism projects and initiatives, many planners now strive to understand how the public perceives the tourism industry (Harrill, 2004). Moreover, the opinions of residents about tourism development should be taken into consideration to make the communication between the community and tourists stronger (Eshliki \& Kaboudi, 2012). Having general knowledge of residents' concerns and expectations is important to sustainable tourism development because these concerns relate to local social and economic issues that can assist tourism planners in the type of tourism program to be installed. This, then, could potentially influence community perceptions and expectations. If locals are involved in sustainable tourism, 
then they will more directly perceive its benefits, and in turn, provide better experiences and better value for tourists. Community affection and community participation represent important issues that influence the amount of sustenance for maintainable tourism growth (Saidu-Kamara, 2016). Sustainable tourism requires local communities to participate in tourism decisions to meet local needs. Uninformed and excluded residents tend to adopt a negative attitude towards the development of tourism in the future (Kitnuntaviwat \& Tang, 2008). Achieving sustainable tourism development in a region is only possible by raising the awareness and knowledge of residents and maximizing the cooperation and integration between local community, public, local governments and sector (Duran \& Özkul, 2012).

Given the importance of residents in ensuring sustainability in tourism destinations, the purpose of the current study is to evaluate the residents' opinions about the sustainability of tourism in Selimiye Village, where there are intense tourism activities. This study is important because it evaluates the sustainability of tourism in the village from the eyes of the residents and there is no similar study for Selimiye Village. To this end, the answers to the questions "What are the residents' opinions about the sustainability of tourism activities in Selimiye Village?" and "Do the residents think that tourism activities in Selimiye Village are sustainable?" were sought in the current study.

\section{Study Area}

Selimiye Village is a village of Marmaris Province in the city of Muğla in southwest Anatolia (Turkey). The village is located in the north of the Bozburun municipality and east of the Hisarönü Gulf (Figure 1). Selimiye Village, which was established on a stony slope with no forest cover, has a population of 1213 in 2017 (TUIK, 2018). Selimiye Village is located within the boundaries of the Datça-Bozburun Special Environmental Protection Area. Protection of the natural and cultural resources, economic values and ecological balance will make it possible to develop tourism in a planned manner (ÖÇKB, 2018). 


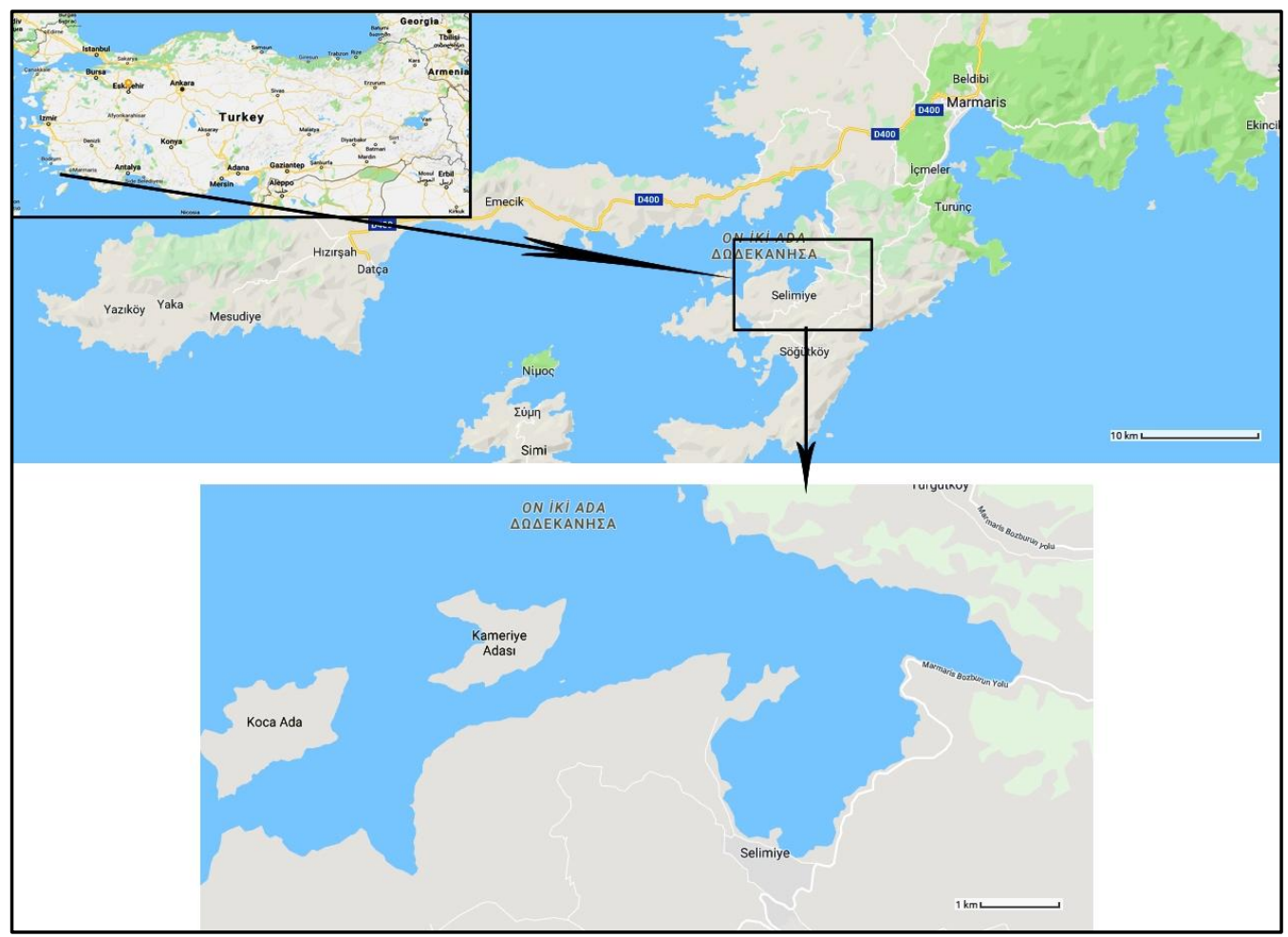

Figure 1. Location map of Selimiye Village

Tourism in Marmaris, Selimiye is one of whose villages, started in the 1960s and showed rapid development in the 1980s. With the rapid progress of mass tourism in Marmaris, the natural and cultural attractiveness of Marmaris has been largely disrupted as a result of intense concretization. Although Selimiye Village is $39 \mathrm{~km}$ away from Marmaris, it managed to remain unaffected from the development of tourism until recent years (Doğaner, 1999). This was so because access to Selimiye Village was only possible from the sea until 1995 as there was no road connection. Before the opening of the highway in 1995, the residents used to make their living by fishing, sponge fishing and almond cultivation. The village had been only discovered by tourists participating in yacht tourism. After the opening of the road in 1995, tourism-oriented accommodation, investments in food and beverage businesses increased rapidly, and today Selimiye Village has become one of the most preferred destinations particularly through the help of social media (Photo 1). 


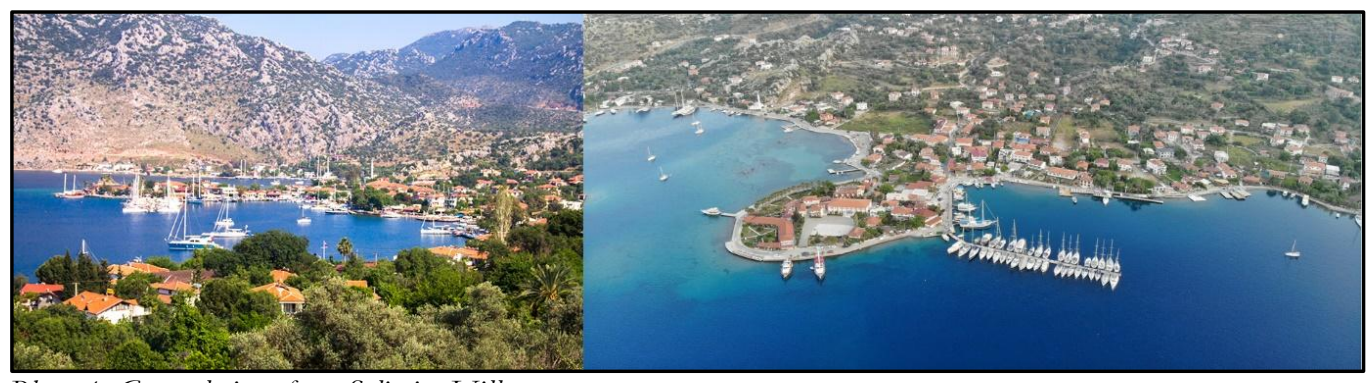

Photo 1. General views from Selimiye Village

(Source: https://kesfetsek.com/ egenin-cennet-koselerinden-selimiye-marmaris/; www. locahotel.com/services/)

When the previous studies on Selimiye Village are reviewed, it is seen that the village was briefly mentioned in the works by Yazıc1 (2007), Oruç (2010), Yılmaz (2010), Taşligil (2008) mainly focusing on the Datça-Bozburun Special Environmental Protection Area. The only study conducted to determine the effect of tourism activities in Selimiye Village on spatial elements and architecture is by Yörür et al. (2018).

\section{Methodology}

The current study employed the case study design; one of the qualitative research methods.

\section{Data collection and analysis}

In the collection to the data in the current study, the interview technique was used. In the selection of the interviewees, the maximum variety sampling; one of the purposive sampling techniques, was used. In-depth interviews were conducted with 28 people on different days in August, 2018. According to the maximum variety sampling, great care was taken to ensure variety among the interviewees in terms of gender, age, their engagement in tourism and continuing their traditional livelihood activities.

The semi-structured interview form was developed on the basis of the factors from the Sustainable Tourism Attitude Scale developed by Choi and Sirakaya-Turk (2005). These factors are environmental sustainability, social costs, economic benefits, community participation, long term planning, visitor satisfaction, community-centered economy. The interview questions were developed by considering each factor as a theme and the questions were constructed under these themes.

The collected interview data were analyzed by using the descriptive analysis technique, one of the qualitative research techniques. The data grouped under themes were evaluated with direct quotations and comparisons.

\section{Results}

Within the context of the study, a total of 28 people were interviewed. Of the interviewers, 11 are females and 17 are males. Of the interviewees, 7 are in the age group 18-30 years old, 10 are in the age group 31-45 years old, 7 are in the age group 46-65 
years old and 4 are in the age group 65 and over. The occupations of the interviewees show a great variety as follows: a barber, 2 boat tour organizers, a cafe owner, a construction materials dealer, a fish cook, a goat farmer, 2 hostel owners, 3 housekeepers, a market cashier, an old almond farmer, 2 old fishermen, an old restaurant owner, a receptionist, a restaurant owner, a small market owner, a traditional bread maker, 3 waiters, a wife of an hostel owner, a wife of an old fisherman, a wife of a restaurant owner, a yacht cleaner/cook.

The data collected from the interviews were analyzed under the pre-designated themes of environmental sustainability, social costs, economic benefits, community participation, long term planning, visitor satisfaction, community-centered economy.

Environmental sustainability: In relation to the effect of tourism in Selimiye Village on the environmental sustainability, first the question "What is the effect of tourism on the natural and cultural values of this village? Does tourism contribute to the protection or destruction of these values? How?" was asked to the participants. Opinions expressed by the participants in response to this question are given below:

"As there are no big hotels, there is not much environmental pollution. Here the accommodation organizations have generally 10 rooms and at most 24 rooms" (R23, male, 48 years old, hostel owner).

"The hotels have not many rooms and they do not dump their wastes into the sea. Hotel owners do not pollute the sea" (R17, male, 26 years old, hostel owner).

"The most valuable asset of the village is its sea. A lot of yachts visit the village in summer months. These yachts pollute the sea. If these yachts anchor outside the bay and use boats to visit the village, it will be better" (R24, male, 34 years old, waiter).

"Yachts anchor at quays on the shore. They leave all their wastes there. There is always oil and detergent layer on the surface of the sea. People do not want to swim" (R19, male, 42 years old, boat tour organizer).

"There are many quays along the coastline. It is not possible to enter the sea due to these quays and the yachts anchoring at these quays. Guests sitting in restaurants cannot watch the sea, rather the yachts" (R27, male, 40 years old, cafe owner).

"We used to have almond trees. Many of these trees have been felled. In the cleared lands, houses and hostels were constructed. This was already barren land, we have lost many of our trees" (R3, female, 68 years old, wife of old fisherman).

"There is no sewage system in the village, we use cesspools. In crowded seasons, we experience serious problems with wastes. Cesspools overflow, smell disgusting” (R21, male, 38 years old, barber).

Another question asked to the participants under the theme of the environmental sustainability of tourism: "In your opinion, how does the fact that Selimiye Village is within the borders of a special protection area affect tourism and local community?" Opinions expressed by the participants in response to this question are given below:

"As it is within the borders of a special protection area, the construction of new buildings has been banned. Yet, there are some constructions and they are continuously fined. Thus, we are not happy" (R11, male, 52 years old, construction materials dealer).

"We cannot see any benefits of being within the borders of a special protection area. The village still does not have a master plan. All the constructions are illegal. Then they are pulled down as they are illegal. 
But we do not know what to do. We should be told what to do" (R23, male, 48 years old, hostel owner).

"This does not protect anything. They cannot protect the sea; prevent people from polluting the sea. We only see the effect of the statues of special protection area while illegal constructions are pulled down" (R13, male, 42 years old, fish cook).

"The special protection authority prepared a master plan in early 1990s. Many lands were given the status of public property. But what happened then? People objected, bribed. And this master plan has never been put into effect, it disappeared. The lands defined as public property then are full of private houses now" (R11, male, 52 years old, construction materials dealer).

The final question asked under the theme of environmental sustainability is "What should be done to protect the sea and natural-cultural values? What do you as a member of the local community do protect the environment?" Opinions expressed by the participants in response to this question are given below:

"They wanted to build a 90-room hotel. All villagers gathered signatures and prevented the construction. We don't want a big hotel in our village. They both pollute the sea and prevent local people from earning money” (R23, male, 48 years old, hostel owner).

"In order to prevent the pollution of the sea, yachts should not be allowed to approach the village and anchor at the quays on the coast" (R24, male, 34 years old, waiter).

"What more should be done for protection? Nothing is done" (R1, female, 44 years old, wife of hostel owner).

When the data obtained from the interviews made with the residents within the context of the sustainability of tourism are examined, it is seen that the adverse effects of accommodation businesses on the environment, particularly on the sea, which is the most important attraction of the village, are not very serious as they have small number of rooms and low capacity. On the other hand, they think that the sea is getting increasingly more polluted and loses its attraction. The reason for this, according to them, is anchoring of yachts at quays and dumping all their wastes into the sea. The residents are not content with the village's status of special protection area. They are of the opinion that the status of special protection area does not contribute to the protection of the area and makes their lives more difficult by preventing them from constructing buildings. Thus, it can be concluded that the residents are not conscious about the effect of conception of protection on the sustainability of tourism. While the only meaningful attempt of the public in terms of protecting the tourist values of the village was to prevent the construction of a high-capacity hotel in their village; they do not have any other attempt directed to protection.

Social costs: In order to elicit the residents' opinions about the social costs of tourism, the participants were asked the question "With tourism, how did the areas used in the village change?, Do you go to places designed for tourists? Why?".

"We go to the places established for tourists, but rarely because they are very expensive. We spend much of our time in our own boats" (R8, male, 48 years old, boat tour organizer).

"There used to be restaurants on the coast, they were all our people's. Now we have only Sardunya Restaurant, its owner is our villager. The others have been sold or rented. They have all become luxurious places. We need cafe houses to drink tea, play games. There is no place for the villagers on the coast" (R22, male, 63 years old, small market owner). 
"We should blame ourselves. We sold our lands. Then what happened? My children spent all the money. Now we are just talking about old days. We are now working as waiters, cleaners, bakers in our own places" (R28, male, 75 years old, old fisherman).

"We used to enter the sea from anywhere in the past. Now, the businesses place their sun beds nearly into the sea. They want a lot of money to use their facilities. There is no place where the public can swim. We cannot swim in our own sea" (R2, female, 42 years old, wife of restaurant owner).

"How can we go to these places? They are both very expensive and tourists do not like us, our clothes, our speech" (R25, female, 42 years old, yacht cleaner, cook).

"Now everything is for tourists in the village. Three big markets are opened in the summer months. Then, they are closed when tourists leave. All the establishments on the coast are closed. There is no place where the public can go and spend time" (R24, male, 34 years old, waiter).

"I have my own place on the coast. It was a restaurant but my children could not run it. I have rented it to a market. I have a good income but when it is evening, I have no place to spend time on the coast. Therefore, I go my bome on the slope of the village" (R15, 72 years old, old fisherman, old restaurant owner).

In relation to social costs, the residents were asked the questions "How does the crowd affect you in the summer months? and "How do tourists behave?, Are you satisfied? Do you feel disturbed?; How are the public and young people affected from the behaviors of tourists?". Residents' responses to these questions are given below:

"The village has a capacity of accommodating nearly 5000 people. There are also daily visitors in addition to people coming on yachts. Nearly 10 thousand people come. When it is crowded, tap water is not available. We bring water in tanks. This is not enough most of the time" (R19, male, 42 years old, boat tour organizer).

"Normally the population of the village is 800 people but in the summer months this number can reach 10000. The infrastructure of the village cannot bear such a crowd. There is always a smell of sewage. Sewage trucks remain inadequate. Even going home can be difficult due to bad smell; we are staying in the boat throughout the summer season" (R8, male, 48 years old, boat tour organizer).

"Coastal areas are good but when you go to inland areas in hectic times, you see wastes outpouring from trash cans, everywhere is in mess; we cannot cope with flies. We are afraid that we will be ill" (R12, female, 40 years old, housekeeper).

"There is a traffic problem in the village. Do you believe it? There is no place to walk among cars. People are always fighting for park places. This makes us disturbed" (R20, male, 55 years old, old restaurant owner).

"Tourists behave aggressively against the locals. When they come on boliday here, they think that they have bought the village" (R24, male, 34 years old, waiter).

"The quality of tourists coming here has dropped, they used to be better. For the first time, burglaries occur in our village" (R4, male, 21 years old, waiter).

"We used to have richer tourists when the village had no access on land. They used to appreciate the locals. After the opening of the road, everybody is coming. Now, tourists do not want to be in the same environment with the villagers. Thus, we feel disturbed. We are like strangers to our own village" (R9, female, 51 years old, traditional bread maker).

"As tourists behave rudely, the locals cannot stop treating them badly. Residents are always attempting to deceive tourist" (R7, female, 22 years old, market cashier).

As a result of the evaluation of the social costs dimension of the sustainability of tourism in Selimiye Village in light of the residents' opinions, it was concluded that the residents 
have been negatively affected from the development of tourism in social respect. The residents are of the opinion that all the places in the village are for tourists and there is no place to meet the needs of the villagers. Moreover, it is also emphasized that the places cannot be used by the residents as they are very expensive.

The participants also stated that due to excessive number of tourists visiting the village, infrastructure remains inadequate, leading to negative effects on the life quality of the villagers. They are also unhappy about the behaviors of tourists against them in general.

Economic benefits: In relation to the theme of the economic benefits of tourism, the participants were first asked the question "Do you gain any income from tourism? How?, Do you think that the residents gain adequate economic benefits?" The responses given to these questions are given below:

"In this village, everyone is earning money from tourism. Everyone is doing something. Some bake bread, some do cleaning, some run hostels, some run restaurants, some sell lands. Less or more, but everyone earns" (R17, male, 26 years old, hostel owner).

"Villagers rent out their places to people coming from outside in return for high prices. Thus, villagers earn money without doing anything regarding tourism" (R5, female, 25 years old, housekeeper).

"I am not doing anything related to tourism anymore, I rented out my restaurant. I am not doing anything and my income is better, I do not get tired. In winter, I either go to Marmaris or go abroad" (R20, male, 55 years old, old restaurant owner).

"Villagers do not gain much income from tourism, they can only gain something for 3 months. They need to get by with this money throughout the rest of the year" (R8, male, 48 years old, boat tour organizer).

"Villagers earn money by selling their lands, it will end somehow. They spend the money they gained by selling their lands very fast. Then they become broke" (R2, female, 42 years old, wife of restaurant owner).

"I used to be a fisherman. When tourism stared in the village, I started to sell my own lands. I earned a lot. But I spent all. Then, I earned again by working as an estate agent. I worked as a contractor, I made much money. But now all is over. Now I am selling construction materials. It is again related to tourism. But, my income is not as it was before anymore" (R11, 52 years old, male, construction materials dealer).

"I am working as a cashier in a market in the summer months. But I only work for four months. When the market is closed, I am jobless" (R7, 22 years old, female, market cashier).

In relation to the economic benefits of tourism, the following questions were then asked to the residents "How have the traditional ways of making their living (e.g., almond cultivation, fishing etc.) been affected from tourism?, "Which lines of businesses have emerged with tourism?, What is your level of satisfaction with these new lines of businesses?". The participants expressed their opinions in response to these questions as follows:

"Fishing used to be good in the past; we could earn well throughout the year but now it is also problematic. Fishing is allowed for a very limited period of time in a year" (R23, male, 48 years old, hostel owner).

"When I was young, I used to dive for sponge. We were engaged in fishing until tourism started to develop. Our income was good. With the development of tourism, my children started to do different jobs. Thus, I gave up fishing. We had many lands. I have sold almost all; my children have spent all the money" (R28, male, 75 years old, old fisherman). 
"We used to earn our living by fishery with my husband. Now I am baking bread and sell to hotels and restaurants. My income is good in summer, but there is no work in winter" (R9, female, 51 years old, traditional bread maker).

"When we got married, we used to get by with fishing; we started to run a hostel. We could not run it. Now I am working as a cleaner in a hostel. It is not like my own business, I get very tired" (R12, female, 40 years old, housekeeper).

"My husband is a yacht captain, I am working as a cleaner and cook in the yacht in the summer months. We are earning money together" (R25, female, 42 years old, yacht cleaner, cook).

"We used to have many almond trees, we used to make much money from almond. Then, we have sold the lands where there were almond trees, they were felled and houses were built there. We have still almond trees but few" (R16, female, 75 years old, old almond farmer).

"We used to have many goats, as the region is suitable for goat raising. Now we have fewer. I am selling goat milk to ice-cream producers. Though not much, I earn some money" (R26, male, 46 years old, goat farmer).

"Everyone used to be a fisher in this village. They used to earn less but to earn throughout the year. Now we earn good money but just for two months" (R24, male, 34 years old, waiter).

"I used to be a fisherman, now the closed season is very long and species of fish have also decreased. Yet, I am still in fishing, but not as a fisherman, as a fish cook. We are buying fish from fish farms and then I cook on demand and sell" (R13, male, 42 years old, fish cooker).

When the residents' opinions about the economic benefits of tourism; one of the themes of sustainability of tourism in Selimiye village, were evaluated, it was found that less or more the villagers earn money from tourism. As can be understood from the statements of the participants, the villagers sold their lands especially in the first years of fast development in tourism to outsiders and made a lot of money but they could not use this money to make investments in tourism and they spent it. Some of the residents run businesses in tourism but they could not be successful so they sold or rented out their establishments to outsiders. In this way, they continue to generate income from tourism. The residents think that the village's main livelihoods; fishing and almond cultivation, have almost been abandoned as a result of developing tourism. Professions such as bread baking, cleaning, and cookery, where women gain direct earnings, have emerged with tourism. However, the public is moderately satisfied with the emerging occupations. While women are satisfied that they are earning their own incomes, the general public expresses their dissatisfaction with the fact that in winters they do not have earnings.

Community participation: In order to evaluate the importance of community participation in sustainable tourism, the participants were asked the following questions; "Have the demands of the community been taken into consideration while taking decisions in relation to the development of tourism?, "If you were the authority responsible for the development of tourism in this village, which decisions would you take for the maintenance and sustainability of tourism?". The residents expressed their opinions about community participation as follows:

"There is nothing done for the villagers in this village. Our demands have never been asked" (R18, female, 24 years old, waiter).

"There is no place to meet our needs. As it is very crowded in summer, we cannot hold our wedding ceremonies. Thus, we are holding our wedding ceremonies in late fall and early winter. We do not have a closed area to hold our wedding receptions. When it rains during the reception, our wedding reception gets 
spoiled. Our children want playgrounds but there is no place to establish them. There is only one small park, in a school. There is no other place for children to play in this village. There is no place for our youth to spend time. There is no job in winter; we are just drinking on the top of the hill. This is our only fun" (R4, 21 years old, male, waiter).

"I am not sure that some decisions are taken for the development of tourism. Even if some decisions are taken, our opinions are not asked. I think even the opinions of the local governor have not been asked." (R17, male, 26 years old, hostel owner).

"In my opinion, first the public should be made satisfied. If their demands are satisfied, they might think that tourism is good" (R23, male, 48 years old, hostel owner).

"If I were given the authority, I would try to find ways of reducing prices in restaurants, hotels. As they are too expensive, tourists stay for a short period of time and then leave. Or they come for one day. There is no benefit to the villagers; only the crowd" (R6, male, 24 years old, receptionist).

"If I were the authority, I would first try to improve the infrastructure. Due to disgusting smell, tourists will not come any more" (R8, 48 years old, male, boat trip organizer).

"Tourists are coming for the sea. If they asked me, I would recommend them to go to slopes of the hills, to walk there, to watch the scenery, to collect almonds and to go fishing" (R17, male, 26 years old, hostel owner).

When the residents' opinions about the community participation for sustainability in tourism are evaluated, it is seen that community participation in Selimiye Village is out of the question. There are no attempts to establish facilities for the use of the residents in the village and their opinions about the development of tourism have not been taken into consideration. The residents suggested that prices should be more reasonable, infrastructure should be improved and variety should be brought to tourism activities.

Long term planning: In order to determine the opinions of the residents about planning, one of the important criteria for the maintenance of sustainable tourism, the questions "Is there a long-term tourism planning for Selimiye?", "In the absence of such a planning, what do you think about the future of tourism in this village?" were asked to the participants. The opinions of the residents in response to these questions are given below:

"There is no plan for tourism. We do not have even a master plan" (R21, male, 38 years old, barber).

"Here the tourism activities are directed to domestic tourists, foreign tourists do not come. The income obtained from the domestic tourism is lower; it does not make much contribution. This should be changed. For sustainable tourism in this village, measures should be put into effect to attract foreign tourists, more promotion is needed" (R10, male, 47 years old, restaurant owner).

"In my opinion, tourism is over in this village. The infrastructure is not enough for so many people. Local people gave up tourism. Strangers are running tourism facilities in the village" (R21, male, 38 years old, barber).

"I do not think that tourism will survive for a long time. The sea is polluted, we have no fish. Tourists come for them" (R28, male, 75 years old, old fisherman).

One of the most important issues in terms of sustainability of tourism, the long-term planning is the weakest side of Selimiye Village. There is no plan prepared to contribute to the sustainability of tourism in the village. 1 / 25.000 scaled Environmental Plan has been revised and started to be implemented for the village, which is within the borders of a special environmental protection area, in 2014. According to this plan, Selimiye 
coastal region is defined as "rural settlement area" and the slopes are defined as "rural development area". The regions to the east of the development area are defined as "marginal agricultural area" and "agriculture-oriented rural tourism area" (Yörür et al., 2018). It seems to be clear that this plan was made by the central authority without considering the present state of the village. The coastal region, which is defined as rural development area", is full of accommodation facilities and restaurants; thus, it is exactly a tourism area.

It is apparent that the residents have negative opinions about the sustainability of tourism in the absence of a long-term planning.

Visitor satisfaction: Within the context of the visitor satisfaction theme; one of the components of sustainable tourism, the following questions were asked to the residents; 'Which features of Selimiye do you think tourists are or aren't satisfied with?, "What should be done to enhance their satisfaction?, "What should the local community do in this regard?" The opinions of the residents expressed in response to these questions are given below:

"In recent years, the number of tourists coming to Selimiye has increased too much. The village is bighly popular in social media. People coming to village share few photos taken in the most beautiful places of the village in social media. People seeing these photos want to come. People coming here for the first time get amazed at the sea and scenery. Yet, they cannot stay longer than two days as it is too expensive" (R6, male, 24 years old, hotel staff).

"Tourists come to the village with great hopes. But when they come, they start to complain about not finding a free place to go to sea, high prices in restaurants, crowds, trashes, bad smell" (R18, female, 24 years old, waiter).

"The tourists coming to our restaurant are richer tourists; they are coming on their yachts. As they do not see and experience the problems inside the village, they usually leave the village with a great satisfaction" (R10, male, 47 years old, restaurant owner).

"In my opinion, they like walking on the beach at night, sitting in authentic cafes and buying authentic products Tourists find the beach very lively at night" (R7, female, 22 years old, market cashier).

"There are some tourists coming to the village for many years, but now they feel discontent with the changes in the village, with so many people coming here" (R15, male, 72 years old, old fisherman, old restaurant owner).

"We cannot make everyone happy, but infrastructure-related problems should be immediately solved. With this bad infrastructure, both tourists and the local people are dissatisfied" (R8, male, 48 years old, boat tour organizer).

"When tourists pay 8 TL for one scoop of ice-cream and 10 TL for a glass of tea, they feel cheated. The prices should be reduced to more reasonable levels" (R11, male, 52 years old, construction materials dealer).

"The local community should embrace their village, tourism. If they run their own hostels and restaurants instead of renting them out, if they sell their own products to tourists, then the prices will be lower. Thus, tourists feel more satisfied" (R27, male, 40 years old, cafe owner).

When the residents' opinions about tourist satisfaction, which is important for the sustainability of tourism, are examined, it is seen that the number of tourists visiting the village has increased too much in recent years with the influence of social media and that tourists feel dissatisfied due to infrastructure problems, high prices and crowds. The residents think that these problems can be solved if more importance is attached to 
infrastructure of the village, if residents embrace tourism and thus the number of businesses run by the residents increases, then tourists will be more satisfied.

Community-centered economy: In order to determine the residents' opinions about community-centered economy; one of the important components of sustainable tourism, the participants were asked the following questions; "How many of the residents work in the tourism sector? In which positions do they work?"; "Do the young people in the village receive any training about tourism? Do they work in the village after completing their training?" The opinions of the residents expressed in response to these questions are given below:

"There are very few local businesses left, many people have sold their businesses or rented them out. They do not have any vision, they cannot meet the expectations of tourists" (R1, female, 44 years old, wife of hostel owner).

"Men in the village work mostly as waiters. Women go to hostels for cleaning" (R5, female, 25 years old, housekeeper).

"Almost all the members of the local community have some income from tourism. Some sell lands, some rent their houses, some make bread, some organize boat trips, some carry out passenger transfer, some sell thyme and almond. Bu the number of villagers working insured is small, they work as waiters, cleaners, cooks in hotels, but their social security premiums are paid for only three months" (R12, female, 40 years old, housekeeper).

"Young people go to tourism schools. They generally attend cookery or tourism vocational high schools. When they have graduated, they mostly come to the village to work. There are jobs for them in the village" (R6, male, 24 years old, receptionist).

"I have graduated from the department of tourism administration. I came back to my village. My father had sold a land. With this money, I open a hostel. I am working here with my mother and wife" (R17, male, 26 years old, hostel owner).

"I worked abroad for many years, I received training. Then I came back to my village and opened a restaurant. I continuously expanded it. Now it is the most famous restaurant in the village. Celebrities come to my restaurant. Training, vision and persistence are important. But our villagers gave up too quickly, they mostly preferred easy money" (R10, male, 47 years old, restaurant owner).

Within the context of community-centered economy, the participants were also asked these questions; "Where do the businesses get their products? If they are supplied from the village, which ones?" and "Do you think that you receive a just share from the tourism activities in the village? Why?". The opinions of the residents expressed in response to these questions are given below:

"The businesses do not supply their needs from the villagers as villagers do not produce anything" (R16, female, 75 years old, old almond farmer).

"There is no agricultural land left in the village. All of them have been sold. Restaurants meet their needs from the wholesalers coming to the village" (R26, male, 46 years old, goat farmer).

"Villagers sell their almonds, honey, herbs they collect from hills such as thyme and sage in small stalls. Yet, they are few in number. They are fewer than 10 people" (R20, male, 55 years old, old restaurant owner).

"We used to weave carpets. We used to give them as invitations to weddings. I sold few of them. I do not have them anymore, and there is nobody weaving them" (R17, female, 75 years old, old almond farmer). 
"Our income is good. We have our own place. We don't pay any rent. In summer, our restaurant is full every day" (R10, male, 47 years old, restaurant owner).

"It is very difficult to make the boat full every day. Even if it is full, petrol prices are too high, the prices of fishes we serve for lunch have increased so much that we experience great difficulties. Our profit is very low. If we had not rented our own place, and were running it now, we would have better income" (R19, male, 42 years old, boat tour organizer).

"Here the best money is earned by small markets. These small markets prevent villagers from earning more" (R22, male, 63 years old, small market owner).

In relation to the theme of community-centered economy within the context of sustainability of tourism in Selimiye Village, some positive results for the sustainability of tourism have been reached. These are; almost all members of the local community have some gains generated from tourism, young people receive training on tourism and come back to their village, they work in the tourism sector. What has been found to be negative under this theme is that many villagers sold or rented their lands, hostels and restaurants to people outside the village. The satisfaction level of the villagers having their own businesses is higher.

\section{Conclusions}

The results obtained from this study investigating the sustainability of tourism in Selimiye Village are evaluated under seven different themes in accordance with residents' opinions are as follows:

The environmental sustainability dimension of the tourism activities in the village is evaluated by the residents as moderately positive. Although the village is within a special protection area, there is no protection work other than trying to prevent the construction in the village. Yachts that come to shore in the village and empty their wastes are the biggest pollutants of the sea, which is the most important natural attraction of the village, while low capacity of accommodation facilities results in less pressure on the environment. In a study in the literature, the public's views on environmental protection are in contradiction with the findings of the current study. In this study conducted in Arizona, the residents think that tourism protects the environment (Andereck, Valentine, Knopf, \& Vogt, 2005). Results of another study on the other hand concur with the findings of the current study. In a study conducted in Gana Lake Bosomtwe Basin, the residents are concerned about the possibility of their lake's being polluted, which is the most precious natural asset of the region, as a result of the development of tourism (Amuquandoh, 2010).

The social costs dimension of tourism is evaluated highly negatively by the residents. With the rapid development of tourism, the people have entered into a phase of rapid economic and social transformation. However, this transformation, which seemed to be a gain in the beginning, caused the public to be pushed out of tourism in the long-run. People have started to work in places which used to be their own in the past and in jobs where they can gain lower earnings and the number of places where they feel good has rapidly decreased. The residents have started to feel as if they were strangers to their village. With tourism, a rapid transformation has occurred in the spatial view of the village. The places where the villagers previously anchored their fishing boats have now 
turned into places where the yachts are anchored and the restaurants are located and all the residential areas close to the shore have been turned into accommodation facilities for tourists. Local residents started moving their houses to higher parts of the village. Furthermore, the number of tourists coming to the village exceeds the village's carrying capacity and the problems caused by the insufficiency of the infrastructure of the village have negative effects lowering the quality of life of the people. Unlike the current study, in a study in the literature, the local residents did not realize the effects of spatial transformation. In that study, the results of the survey indicated that the participants were not aware of some of the factors that could hinder tourism activities such as problems related to summerhouses, and environmental problems caused by road construction works and by Turkish Hard Coal Authority (Cengiz, 2012). In another study, the crowded tourist population is negatively evaluated by the local residents (Vargas-Sa'nchez, Porras-Bueno, \& Plaza-Mej1'a, 2011). In a study conducted in Iran, the residents view the environmental pollution, water pollution caused by tourism and its adverse social and cultural effects as negative developments (Eshliki \& Kaboudi, 2012).

The themes of economic benefits of tourism and community-centered economy are evaluated by the residents to be moderately positive. Almost all the members of the local community gain from the tourism activities in Selimiye Village. What is negative here is that their income is lower than the mean income generated in the village. Tourism activities starting as local-people centered is now moving towards the monopoly of the operators coming from outside the village. The residents have changed their status from the owner to the worker in the accommodation and catering sector, which bring higher economic gain. This leads to a decreasing share of the local community from the income generated from tourism. In the literature, there are several studies that have similarities and contradictions with the results of the current study on the economic contribution of tourism. According to a study in Uganda, residents have a positive attitude towards tourism as it results in an increase in their agricultural production and revenues (Lepp, 2007). According to the results of the study carried out in Afyonkarahisar, it was determined that the people actively participate in tourism activities, they look at tourism and tourists positively and they consider tourism as an economic event (Özdemir \& Kervankıran, 2011). In the study in which the residents' views on tourism in Ihlara Valley were evaluated, it was determined that the residents drew attention to the economic dimension of tourism but they could not obtain economic gain in tourism (Varnac1 Uzun \& Somuncu, 2011). In the study conducted in Foça, the views of residents towards tourism activities were generally found to be positive and that high majority of the local community was mainly interested in the economic contributions of tourism (Gümüş \& Özüpekçe, 2009). In the study conducted at Frankenwald Nature Park, the economic dimension of tourism was found to be the main determinant of the satisfaction of the residents with sustainable tourism (Cottrell, Vaske, \& Roemer, 2013).

The themes of community participation and long-term planning are viewed negatively by the residents. There is no plan prepared for the sustainable development of tourism in the village and the villagers' opinions about tourism are not taken into consideration. There are several studies in the literature in which local populations emphasize the importance of tourism planning. According to the study conducted in the state of Texas, residents see tourism as a sector providing them with an economic gain while 
emphasizing the need for environmental protection and long-term planning for sustainable tourism (Choi \& Murray, 2010). In a study conducted in Akçakoca, the participants stated that firstly the infrastructure and superstructure of the district should be improved in a planned way in order to ensure the sustainability of tourism in the district (Duran \& Özkul, 2012).

The theme of tourist satisfaction is evaluated by the residents as moderately positive. According to residents, tourists' satisfaction level is high in terms of natural beauties, while their satisfaction level is low due to problems of the infrastructure of the village, the crowds and high prices. On the basis of their evaluations, it was concluded that tourism activities in the village cannot be sustainable unless necessary measures are taken. The measure to be taken for ensuring sustainability in Selimiye Village can be listed as follows:

Regulations required by the status of special environmental protection area should be better implemented and monitored. The public should be trained about the importance of the conception of protection and the contribution of protection efforts to tourism. A management plan should be prepared for the sustainable development of tourism activities in the village. Under this plan, local businesses should be supported to maximize the economic gain of the people from tourism. In addition, the use of local products should be encouraged in the businesses in the village for the maintenance of traditional almonds, fisheries and agricultural production. Infrastructure of the village should be improved. Control mechanisms for waste disposal of yachts moored in the village should be developed.

\section{Acknowledgement}

I would like to thank my children Ufuk and Doğa and niece Varna Ela, who were with me during the interviews in Selimiye Village, for their patience.

\section{References}

Akis, S., Peristianis, N., \& Warner, J. (1996). Residents' attitudes to tourism development: the case of Cyprus. Tourism Management, 17(7), 481-494.

Almeida-García, F., Pelaez-Fernandez, M., Balbuena-Vazquez, A., \& Cortes-Macias, R. (2016). Residents' perceptions of tourism development in Benalmadena (Spain). Tourism Management, 54, 259-274.

Amuquandoh, F. (2010). Residents' perceptions of the environmental impacts of tourism in the Lake Bosomtwe Basin, Ghana. Journal of Sustainable Tourism, 18(2), 223-238.

Andereck, K., Valentine, K., Knopf, R., \& Vogt, C. (2005). Residents' Perceptions of Community Tourism Impacts. Annals of Tourism Research, 32(4), 1056-1076.

Boley, B. (2013). Sustainability, Empowerment, and Resident Attitudes toward Tourism: Developing and Testing the Resident Empowerment through Tourism Scale (RETS). USA: Faculty of Virginia Polytechnic Institute and State University.

Butler, R. (1980). The concept of a tourist area cycle of evolution:Implications for management of resources. Canadian Geographer, XXIV(1), 5-12.

Cengiz, B. (2012). Local Residents' Perceptions of and Attitudes Toward Sustainable Tourism Planning and Management in Amasra (Turkey). In M. Özyavuz, Landscape Planning (pp. 177-198). Croatia: InTech.

Choi, H., \& Murray, I. (2010). Resident attitudes toward sustainable community tourism. Journal of Sustainable Tourism, 18(4), 575-594. 
Choi, H.-S., \& Sirakaya-Turk, E. (2005). Measuring Residents' Attitude toward Sustainable Tourism: Development of Sustainable Tourism Attitude Scale. Journal of Travel Research, 43(4), 380-394.

Cottrell, S., Vaske, J., \& Roemer, J. (2013). Resident satisfaction with sustainable tourism: The case of Frankenwald Nature Park, Germany. Tourism Management Perspectives, 8, 42-48.

Doğaner, S. (1999). Bozburun Yarımadası: Coğrafi Ortam ve İnsan. İstanbul Üniversitesi Coğraffja Dergisi(7), 29-56.

Duran, E., \& Özkul, E. (2012). Yerel halkın turizm gelişimine yönelik tutumları: Akçakoca örneği üzerinden bir yapisal model. International Journal of Human Sciences, 9(2), 500-520.

Emekli, G. (2004). Sürdürülebilir Turizmin Kaz Dağı Ve Yakın Çevresi İçin Önemi. I. Balıkesir Ulusal Turiz̧m Kongresi Bildiriler kitabı, (pp. 416-432). Balıkesir.

Eshliki, S., \& Kaboudi, M. (2012). Community Perception of Tourism Impacts and Their Participation in Tourism Planning: A Case Study of Ramsar, Iran. ASEAN Conference on Environment-Behaviour Studies, Procedia - Social and Behavioral Sciences, 36, pp. 333 - 341. Indonesia.

Gümüş, N., \& Özüpekçe, S. (2009). Foça'da turizmin ekonomik, sosyal, kültürel ve çevresel etkilerine yönelik yerel halkın görüssleri. Uluslararası İnsan Bilimleri Dergisi, 6(2), 398-471.

Harrill, R. (2004). Residents' Attitudes toward Tourism Development: A Literature Review with Implications for Tourism Planning. Journal of Planning Literature, 18(3), 251-266.

Hsieh, C.-M., Park, S., \& Huh, C. (2016). A Comparison Model of Residents' and Tourists' Attitudes toward Sustainable. 2010 ttra International Conference. US: Travel and Tourism Research Association: Advancing Tourism Research Globally.

Kim, K., Uysal, M., \& Sir, M. (2013). How does tourism in a community impact the quality of life of community residents? Tourism Management, 36, 527-540.

Kitnuntaviwat, V., \& Tang, J. (2008). Residents' Attitudes, Perception and Support for Sustainable Tourism Development. Tourism and Hospitality Planning \& Development, 5(1), 45-60.

Knollenberg, W. (2011). Stakeholders' Attitudes Towards Sustainable Tourism Development In Coastal Communities. USA: East Carolina University.

Lepp, A. (2007). Residents' attitudes towards tourism in Bigodi village, Uganda. Tourism Management, 28, 876-885.

Lew, A., Ng, P., Ni, C.-c., \& Wu, T.-c. (2016). Community sustainability and resilience: similarities, differences and indicators. Tourism Geographies, 18(1), 18-27.

Lottig, K. (2007). Modeling Resident Attitudes On The Environmental Impacts of Tourism: A Case Study of O'abu, Hawai $\%$. USA: University of Hawaii.

Lozano-Oyolaa, M., Blancas, F., González, M., \& Caballero, R. (2012). Sustainable tourism indicators as planning tools in cultural destinations. Ecological Indicators, 18, 659-675.

Nicholas, L., Thapa, B., \& Ko, Y. (2009). -Residents' Perspectives of a World Heritage Site The Pitons Management Area, St. Lucia. Annals of Tourism Research, 36(3), 390-412.

ÖÇKB. (2018). Daţ̧a- Bozburun Özel Cevre Koruma Bölgesi. Retrieved 11 10, 2018, from T.C. Çevre ve Şehircilik Bakanlı̆̆1: http://ockb.csb.gov.tr/datca-bozburun-ozel-cevre-koruma-bolgesi-i-2747

Özdemir, M., \& Kervankıran, İ. (2011). Turizm ve turizmin etkileri konusunda yerel halkın yaklaşımlarının belirlenmesi: Afyonkarahisar örneği. Marmara Coğrafja Dergisi, 24, 1-25.

Rasoolimanesh, S., \& Jaafar, M. (2017). Sustainable tourism development and residents' perceptions in World Heritage Site destinations. Asia Pacific Journal of Tourism Research, 22(1), 34-48.

Saidu-Kamara, V. (2016). Strategy for Sustainable Tournsm In Developing Countries: A Qualitative Case Study On Sierra Leone. USA: University of Phoenix.

Swarbrooke, J. (1999). Sustainable Tourism Management. UK: CABI Publishing.

Timur, S., \& Getz, D. (2009). Sustainable Tourism Development: How Do Destination Stakeholders Perceive Sustainable Urban Tourism? Sustainable Development, 17, 220-232.

TUIK. (2018). Yillara Göre Selimiye Köyü Nüfusu. Retrieved 09 12, 2018, from Türkiye İstatistik Kurumu: www.tuik.gov.tr

Vargas-Sa'nchez, A., Porras-Bueno, N., \& Plaza-Mej1'a, M. (2011). Explaining Residents' Attitudes to Tourism: Is an Universal Model Possible? Annals of Tourism Research, 38(2), 460-480.

Varnacı Uzun, F., \& Somuncu, M. (2011). Kültürel Peyzajın Korunması ve Turizm İlişkisi Bağlamında Yerel Halkın Görüşleri: Ihlara Vadisi Örneği. Ankara Üniversitesi Cevrebilimleri Dergisi, 3(2), 21-36.

Yörür, N., Uysal, D., \& Altınörs Çırak, A. (2018). Selimiye Yerleşmesinde Turizm Eksenli Dönüşümün Kirsal Doku ve Mimari Yapiya Etkileri. Ege Mimarlk. Dergisi(Nisan), 24-29.

Yu, C.-P. (2011). Investigating Resident Attitudes Toward Tourism Development: A Community Quality of Life Perspective. USA: Indiana University. 